\title{
Global trends for patulin adsorption: A review
}

\author{
Tendências globais para a adsorção de patulina: Uma revisão \\ Las tendencias mundiales para la adsorción de patulina: Una revisión
}

Received: 05/16/2021 | Reviewed: 05/22/2021 | Accept: 05/25/2021 | Published: 06/10/2021

Izabela Alves Gomes
ORCID: https://orcid.org/0000-0003-4961-1526
Federal University of the State of Rio de Janeiro, Brazil
izabela.nut@ gmail.com
Eva Marková
ORCID: https://orcid.org/0000-0003-3659-6937
markova.evka7@gmail.com
Slovak University of Technology in Bratislava, Slovak
Janine Passos Lima da Silva
ORCID: https://orcid.org/0000-0002-9465-2987
Embrapa Food Agroindustry, Brazil
janine.passos@embrapa.br
Armando Venâncio
ORCID: https://orcid.org/0000-0002-0723-6134
University of Minho, Portugal
avenan@ deb.uminho.pt
Otniel Freitas-Silva

\begin{abstract}
Patulin is a toxic metabolite produced by several species of fungi. The species that are responsible for the production of patulin enter fruits through bruised and broken skin, causing contamination. Apple-derived products are considered to be by far the most significant dietary sources of patulin. According to the literature, three strategies have been used to break down or remove patulin in food, such as physical, chemical, and biological methods. Degradation of patulin by microorganisms or biodegradation enzymes is an efficient and promising method for the removal of patulin from food. The incidence of patulin contamination continues to be high, despite global efforts to reduce the levels of this mycotoxin at each stage of the fruit production process. Its transformation into other compounds has been reported. However, the toxicities of its byproducts as deoxypatulinic acid, ascladiol, and hydroascladiol should be subjected to an intensive study.
\end{abstract}

Keywords: Detoxification; Biological methods; Mycotoxins; Bacteria.

\section{Resumo}

A patulina é um metabólito tóxico produzido por várias espécies de fungos. As espécies fúngicas responsáveis pela produção de patulina contaminam os frutos por meio de ferimentos naturais e rachaduras, causando a infecção. A maçã e os produtos derivados da maçã são considerados, de longe, as fontes dietéticas mais significativas de patulina. De acordo com a literatura, três estratégias têm sido utilizadas para decompor ou remover a patulina de alimentos, como métodos físicos, químicos e biológicos. A degradação da patulina por microrganismos ou enzimas de biodegradação é um método eficiente e promissor para a remoção da patulina dos alimentos. A incidência de contaminação por paulina continua alta, apesar dos esforços globais para reduzir os níveis dessa micotoxina em cada etapa do processo de produção da fruta. Sua transformação em outros compostos foi relatada. No entanto, as toxicidades destes subprodutos como o ácido desoxipatulínico, ascladiol e hidroascladiol devem ser submetidas a um estudo intensivo.

Palavras-chave: Descontaminação; Métodos biológicos; Micotoxinas; Bactérias.

\section{Resumen}

La patulina es un metabolito tóxico producido por algunas especies de hongos. Los hongos responsables de la producción de patulina contaminan los frutos a través de heridas y grietas naturales, provocando infecciones. Las manzanas y los productos derivados de las manzanas constituyen las fuentes dietéticas más importantes de patulina. Según la literatura, se han utilizado estrategias para descomponer o eliminar patulina en los alimentos, como los métodos físicos, químicos y biológicos. La degradación de la patulina por microorganismos y/o enzimas de biodegradación es un método eficaz y prometedor para eliminar la patulina de los alimentos. La incidencia de la contaminación por patulina sigue siendo alta, a pesar de los esfuerzos mundiales para reducir los niveles de esta 
micotoxina en cada etapa del proceso de producción de la fruta. Se ha informado de su transformación en otros compuestos. Sin embargo, las toxicidades de estos compuestos como el ácido desoxipatulínico, el ascladiol y el hidroascladiol deben someterse a un estudio intensivo.

Palabras clave: Descontaminación; Métodos biológicos; Micotoxinas; Bacterias.

\section{Introduction}

Patulin (PAT) is a toxic metabolite produced by several species of fungi, and it represents a significant hazard to the food or the food chain. It can be found in a large number of fruits, but it is more commonly found in apples. Generally, the amount of PAT in apple-derived products is seen as a measure of the quality of apples used in the food industries (Zhang et al., 2019).

Among mycotoxins, patulin (4-hydroxy-4H-furo [3,2-c] pyran-2 (6H) -one) is a polyketide lactone, with a molar mass of $154.12 \mathrm{~g} / \mathrm{mol}$ and a melting point of $110^{\circ} \mathrm{C}$. It is soluble in water and stable under acidic conditions and heat, which cannot be thermally denatured (Saleh \& Goktepe, 2019a; Zheng et al., 2020). PAT is produced by at least 60 different species of fungi, such as Penicillium expansum (P. leucopus), P. crustosum, P. patulum (P. urticae and P. griseofulvum) and A. clavatus (Vidal, et al., 2019; Diao et al., 2018). The contamination of apple juice by PAT is one of the most important food safety issues worldwide being the species of fungi that are responsible for the production of PAT enter the fruits through bruised or broken skin areas, causing contamination (Sajid et al., 2018).

Recently, fifteen genes involved in the patulin biosynthesis have been identified. Among those, the patE and patH genes have shown to be needed for the production of patulin. (Saleh \& Goktepe, 2019a).

Patulin was first isolated from the Penicillium griseofulvum in 1943 by Harold Raistrick (Saleh \& Goktepe, 2019a). Shortly after its identification, patulin was studied at the British Medical Research Center under the name "tercinin" as an antimicrobial agent against some gram-positive and gram-negative bacteria. However, it did not take long before researchers at the center had identified its toxic effects in 1944 (Saleh \& Goktepe, 2019b).

Its activity as an antimicrobial was seen to be very promising since it proved to be up to ten times more effective in the treatment of infections by Bacillus sp. than Penicillin G. At the time, the substance was named from Penicillium patulum (later named Penicillium urticae and today known as Penicillium griseofulvum). However, between the years of 1950 and 1960, its toxic aspects became evident, both in plants and in animals, which prevented its clinical use as an antibiotic. Since the 1960s, patulin was reclassified, now being known as a toxic secondary metabolite, of fungal origin, that is, a mycotoxin (Basso, 2019).

PAT is a type of enteropathogenic mycotoxin, is rapidly absorbed and causes ulceration and inflammation of the intestinal mucosa. It causes different health problems for humans and animals, including edema, ulceration, inflammation, vomiting, bleeding, and even death (Bayraç \& Camizci, 2019; Xiao et al., 2019).

The analytical determination of PAT represents common challenges observed in the analysis of mycotoxins. One of the biggest issues is sampling, as mycotoxins have a heterogeneous distribution in each sample batch (Vidal et al., 2019).

This work is a review of the literature on the mechanisms of adsorption of patulin where the characteristics of patulin are discussed along with the possible routes of human exposure and the mechanisms of adsorption of this mycotoxin. The review aims to provide food science researchers with information about the levels of patulin in apple-based foods and the possible ways of absorption of this compound. The google scholar, Scopus, and web of science databases between the years 2000-2021 were considered for writing the present review article. This article deals with researches on PAT decontamination, in the sense of recommending ways for PAT mitigation until the finding of food safety for this mycotoxin in food matrices and products. 


\section{Tolerable Levels of Patulin and Risks to the Population}

After England's veterinary crisis in the 1960s, studies on the effects of mycotoxins on plants and animals have expanded (Basso, 2019). Due to the high volatility in water, resistance to heat, and high toxicity, patulin is among a list of mycotoxins in which the levels in food products are regulated (Bayraç \& Camizci, 2019). According to the World Health Organization, the maximum acceptable level of patulin in apple juice is set at $50 \mu \mathrm{g} / \mathrm{L}$ (Saleh \& Goktepe, 2019a). This value is following the recommendations of the Food and Drug Administration (FDA), the National Health Surveillance Agency (ANVISA), and the European Union (EU), in which the last one also limited the level of patulin in solid apples to $50 \mu \mathrm{g} / \mathrm{kg}$, and on apple-based foods for children and/or babies at $10 \mu \mathrm{g} / \mathrm{L}$. In Brazil, only on February 22, 2011, through ANVISA, it was created the first Resolution of the Collegiate Board (RDC) regarding the tolerable limits for patulin in food commercialization through the RDC n. 07/2011, adopting the same values for patulin as the North American and European organizations (Basso, 2019).

According to the recommendation of the European Commission and based on the established level of patulin (43 $\mu \mathrm{g} / \mathrm{kg}$ body weight), the provisional maximum permissible daily dose of patulin was fixed at $0.4 \mu \mathrm{g} / \mathrm{kg}$ body weight. This level was adopted by most of the health risk evaluation analyzes carried out on patulin (Saleh \& Goktepe, 2019a).

Apple products are considered by far the most significant dietary sources of patulin (Rodríguez-Bencomo, et al.,2020) as shown in Table 1. This occurrence is justified due to the physicochemical properties of the fruit, such as the water activity, which are the favoring factors for germination of the fungus spores. Therefore, the concentration of patulin in raw apples, as well as juices and apple-based products is used as a quality indicator (Saleh \& Goktepe, 2019a).

Patulin also contaminates several other foods, including apple, dried figs, and corn. Currently, patulin is considered to be a global toxin, and many countries monitor its residues in food (Zhao et al., 2019).

Table 1. Food contaminated with patulin.

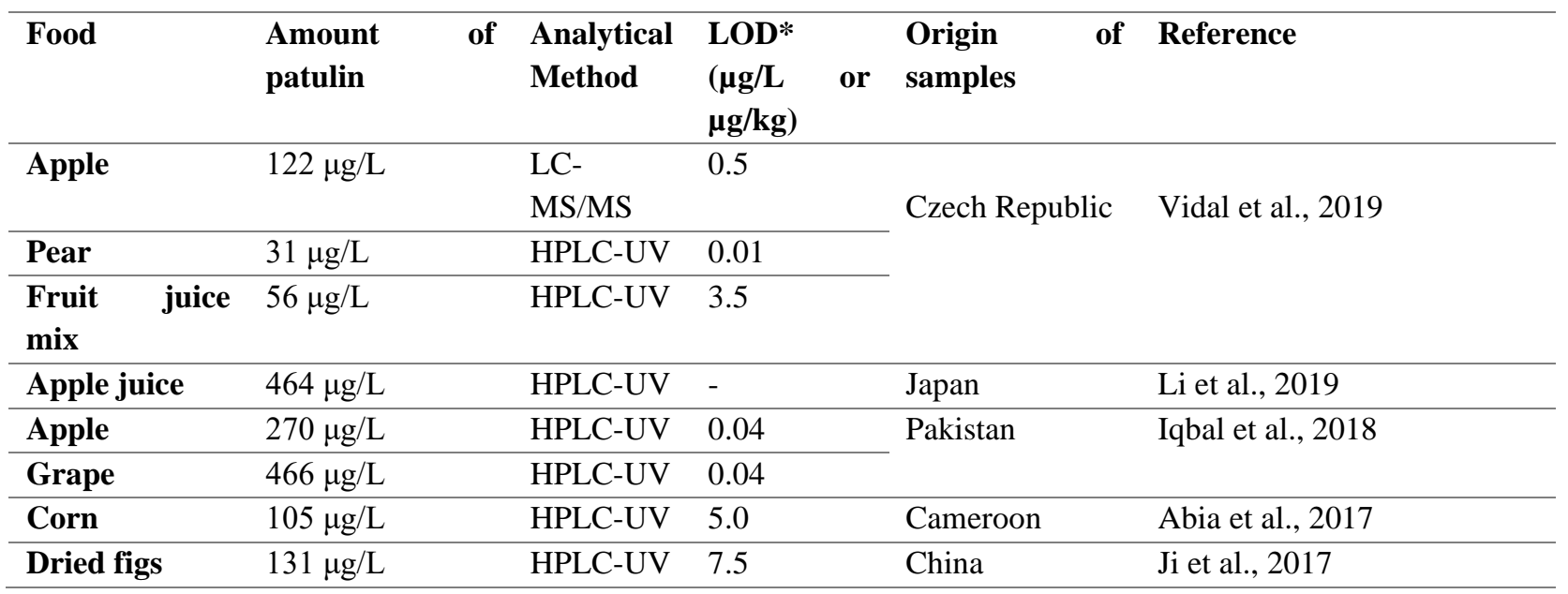

*LOD: Limit of detection. Source: Authors.

The incidence of patulin in recent research has pointed out the importance of strengthening strategies to control patulin during food production. Cleaning, washing, milling, and pressing can indicate a reduction of up to $55 \%$ patulin. Heat treatment showed a limited effect of the reduction of patulin in apple juice, as it was observed a reduction of $26 \%$ of patulin with a treatment of $100{ }^{\circ} \mathrm{C}$ for 20 minutes. Based on these results, the reduction of patulin in apple juice under industrial pasteurization conditions (a heat treatment used in fruit and vegetable products) does not allow for greater results, which means that only a low reduction in the patulin content can be expected using pasteurization (Vidal et al., 2019). 
Over the past few decades, consumers have become more aware of the health and quality of the food and, as a result, research on food safety has increased. The evaluation of patulin contamination in fruits and vegetables has become an important factor to ensure the quality of these products (Basso, 2019). Therefore, it is of great practical importance to develop a method for the detection of patulin traces in food (Zhao et al., 2019).

Based on the high incidence of patulin, concerns were raised about the toxicological effects of patulin on humans and animals through consumption. Patulin causes several chronic health effects on genetics, immunity, and the central nervous system in animals, even though its effects on humans are not yet clear (Sajid et al., 2018).

Although the information on patulin absorption is rare, the bio-accessibility observed in vitro is large, especially on the oral (87\%) and gastric (82\%) phases (Vidal et al., 2019). Several studies have revealed that patulin accelerates the intracellular production of oxygen reactive species (ORS), leading to the damage of many vital macromolecules, such as proteins, enzymes, and DNA (Ramalingam et al., 2019).

\section{Patulin Adsorption Mechanisms}

The patulin content found in the final processed foods is usually lower than the content found in raw materials since processing steps can actively contribute to its reduction. Among these, some procedures stand out, such as the clarification process, the filtration and enzymatic treatment during the juicing process, and the fermentation in the wine production. In general, controls on all the stages of apple processing, such as homogenization, pulping, pasteurization, and aseptic packaging, can contribute to the reduction of the final levels of patulin. The stability of patulin is illustrated by its presence in apple-based products, such as juices, jams, and baby foods, even after all the industrialization process suffered by these foods (Basso, 2019).

Based on the adverse effects of patulin on human health and the quality of agricultural products, researchers have been looking for ideal methods for the degradation or the removal of it from contaminated food (Zheng et al., 2020; Diao et al., 2018). As pre-harvest treatments do not always guarantee sufficiently low levels of patulin in juices, different approaches are being investigated to remove or degrade this toxin during food processing (Rodríguez-Bencomo et al., 2020).

In addition to patulin analysis, detoxification attempts have become an important factor in food safety. There are some methods to reduce the level of patulin during the pre-harvest, harvest, and post-harvest steps of the apple juice manufacturing process to ensure the integrity of the final product. Recently, adsorption methods using different bio-sorbents have been studied for both aqueous solutions and juices (Bayraç \& Camizci, 2019).

Many physical and chemical approaches have been developed for the detoxification of PAT in apple juice and apple-based products. However, some disadvantages, such as safety problems, possible losses in nutritional quality, chemical risks, limited efficacy, and high costs have been registered for these approaches. In addition to the chemical and physical approaches, recent interest has been observed regarding the use of biological methods for the removal of PAT from fruit juices, particularly, the bio-sorption method using inactivated microbial cells (Sajid et al., 2018).

Several factors make the control of patulin and the producing fungi even more complex, such as climatic conditions, geographic location, year of production, pre, and post-harvest treatments, damage to the surface of the fruits, and storage conditions. Sensitive, accurate, and robust analytical procedures are necessary for the qualitative and quantitative analysis of mycotoxins (Vidal et al., 2019).

Adsorption is considered to be the most effective way to remove PAT in juices, due to the convenient operation and without introducing any new threats. With technological advancements, researchers have been developing a series of new adsorbent materials with high adsorption capacity and good stability. Some of them have effectively been used for patulin 
remotion, such as silica-based materials, carbon nanotubes, and organic metallic structures. Synthetic adsorbents generally have good adsorption effects, but those are limited for practical application due to the high cost, complicated preparation processes, and potential safety risks (Qiu et al., 2018).

Recently, bio-waste from agriculture and industries, including microbial cells, algae, plant biomass, and organic sludge, have been considered as fascinating adsorbents as a result of their cost-benefit, respect for the environment, and some interesting properties (Qiu et al., 2018).

According to the literature, three strategies have been used to break down or remove patulin in food, being those physical, chemical, and biological methods (Figure 1). Physical-chemical methods have been extensively studied and some new advanced techniques have been used in practical production. Most of the biological methods were studied only on a laboratory scale even though they have more advantages, such as high safety and efficacy of detoxification (Diao et al., 2018).

Figure 1. Currently measures for patulin decontamination.

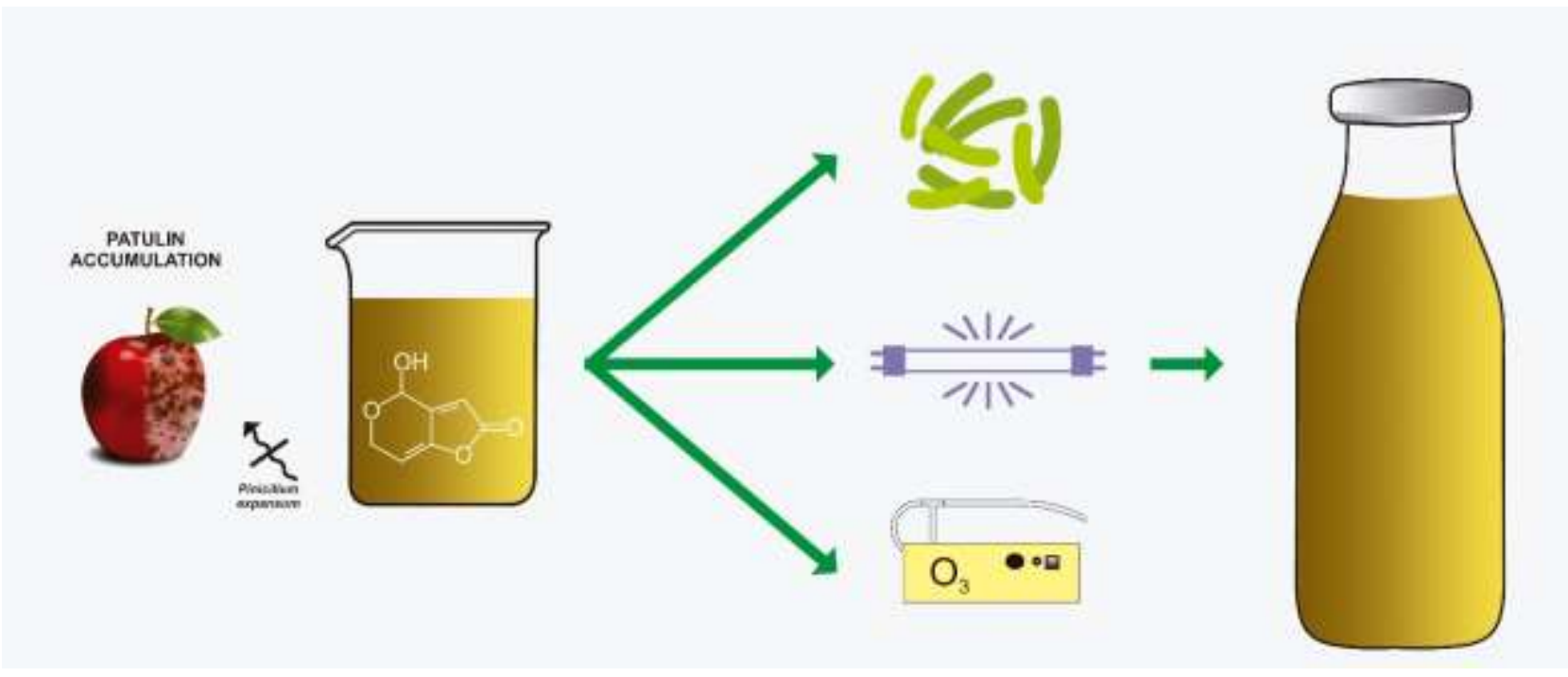

Source: Authors.

The physical methods involve sorting, washing the fruit with high-pressure water, refrigeration, juice clarification, filtration, adsorption, pasteurization, and radiation to treat raw materials, such as apples, to avoid contamination of patulin. Physical methods work well but require a considerable amount of labor and material resources, which are expensive methods and can even affect product quality (Zheng et al., 2020).

For the chemical methods, it is included ammonia and potassium permanganate, which can reduce the content of patulin in the juice by more than $99 \%$. This technique is the most effective way of detoxifying patulin, but it leads to serious damage to the quality of the product. In addition, sulfur dioxide, ascorbic acid, $\mathrm{N}$-acetylcysteine and glutathione, and calcium D pantothenate can reduce the amount of patulin in the juice. However, the addition of these chemicals requires a thorough understanding of the reaction mechanism, that is, whether the reaction products are toxic. In addition, some of these chemicals can seriously decrease the quality of the product by destroying its nutritional content and flavor (Zheng et al., 2020).

The biological methods, especially the direct degradation of patulin by an antagonistic microorganism, have shown great prospects for application in the control of patulin contamination. However, several aspects need to be considered before using these microorganisms. Firstly, it is necessary to investigate whether patulin is adsorbed or degraded by the microorganisms. Degradation of patulin by microorganisms could prevent further over-processing if the patulin were 
transformed into a less toxic compound or a non-toxic compound. For this, the patulin can be reduced through an enzymatic action (Zheng et al., 2020).

The use of yeast and bacteria has also been studied for several years for their ability to degrade or inactivate patulin. These microorganisms are effective in controlling blue mold infection, as biocontrol agents, such as Rhodosporidium kratochvilovae, Pichia caribbica, Metschnikowia spp., and Lactobacillus plantarum. All of these microorganisms demonstrated the ability to protect apples against blue fungi and also to prevent the accumulation of patulin (Basso, 2019).

Microorganisms have been widely used to decrease contamination, for example, heavy metals, dyes, and mycotoxins. Some inactivated microorganisms are effective for the removal of PAT in simulated juice aqueous solutions, while their adsorption capacity decreases noticeably when applied in apple juice. The most probable reason is that some substances in the juice may occupy the PAT binding sites (Qiu et al., 2018).

Although physical-chemical methods may have varying degrees of success, the limited effectiveness and loss of important nutrients still prevent their application in the food industries. Biological methods have been recognized as the promising solution for mycotoxin decontamination, and are being widely studied (Li et al., 2019).

\subsection{Physical methods}

The physical treatment strategies involve strengthening the selection and the cleaning of raw materials, physical adsorption, and clarification. The selection of high-quality raw materials is the first step to reduce or avoid contamination by PAT or the production in food (Wei et al., 2020).

The processing for the removal of patulin in foods has low-cost and it is easily operable with high detoxification efficiency (Diao et al., 2018).

Currently, the adsorbent is widely used in the physical area for the removal of PAT in fruit juices. Magnetic chitosan, resin, and activated carbon are often chosen for the absorption of PAT in the food industry. The resin adsorption is the most commonly used method to remove PAT during the manufacture of industrial apple juice (Wei et al., 2020).

The application of high-pressure hydrostatic processing (pulsed or continuous) and its effects on the patulin content, leads to degradation of up to $62 \%$, but only for a low initial patulin content $(5 \mu \mathrm{g} / \mathrm{L})$. The effectiveness of high pressure in the degradation of patulin depends on the composition of the juice, particularly in the presence of compounds containing thiol groups (Rodríguez-Bencomo et al., 2020; Qiu et al., 2020; Gonçalves et al., 2019).

Treatments based on irradiation with light have also been tested, where the researchers have applied ultraviolet (UV) light (20) in contaminated apple juices. It was noticed that the effectiveness of the patulin degradation depended on the wavelength, obtaining $90 \%$ of degradation at $222 \mathrm{~nm}$ with minor color changes. In addition, physical methods such as UV light, have the advantage of degrading certain organic contaminants, without the formation of taste or odor during the treatments (Wei et al., 2020; Tang et al., 2019). Meanwhile, UV can lead to the formation of furans, which has been identified as a highly carcinogenic compound for humans. Even though these studies are promising regarding the effectiveness of patulin degradation, especially in the case of light treatments, none of them determined the type of degradation products generated, which is a limiting aspect for its application in food products. The development of physical methods to remove patulin depends on the development of special equipment (Rodríguez-Bencomo et al., 2020).

\subsection{Chemical methods}

Chemical methods have great potential for detoxifying mycotoxins such as patulin and are probably the most easily suited method for commercial application in the food industry today. In the 1970s, people used effective chemical additives to remove patulin from food. Sulfur dioxide, ascorbic acid or ascorbate, ammonia, acid or alkaline potassium permanganate, 
sodium benzoate, potassium sorbate, ozone, thiamine hydrochloride, pyridoxine hydrochloride, phenolic compounds, and calcium d-pantothenate have already been used to successfully degrade patulin (Diao et al., 2018; Wei et al., 2020).

Among the chemical additives, ozone has been widely used to detoxify patulin in foods, due to its high safety, low cost, it does not generate toxic waste, is environmentally friendly, and is easy to operate (Diao et al., 2018). The ozone gas can reduce the amount of patulin in food by up to $98 \%$ after 1 minute. On the other hand, it introduced new impurities to it or led to the loss of important nutrients that limit this application in the food industry (Tang et al., 2019).

However, only a few additives have been reported in the literature for removing PAT directly from food. Chemical methods, such as ozone degradation, remained mainly in the experimental stage due to uncertain safety, few results, or other limitations concerning practical applications (Wei et al., 2020).

Patulin can be completely degraded into $\mathrm{CO} 2$, oxalic acid, diglycolic acid, and $\mathrm{H}_{2} \mathrm{O}$ in high ozone concentration or sufficient ozonation time, attacking two ethylene double bonds conjugated in its chemical structure (Vidal et al., 2019). The presence of oxygen and free radicals is necessary for rapid degradation, which limits its application in juices. Chemical methods are economical and efficient if the presence of unknown reactions or toxic by-products with the use of these chemicals is assured (Rodríguez-Bencomo et al., 2020).

\subsection{Biological methods}

Biological methods refer to any methods that utilize active or inactive microorganisms or enzymes for the reduction of patulin in food. Based on the patulin reduction method, the biological methods have been classified into two types: adsorption and degradation. There were no significant differences observed in the efficiencies of patulin removal by living or dead bacteria (Vidal et al., 2019; Wei et al., 2020).

The most recent studies have led to the identification of two main products of patulin degradation by microorganisms, which are the Z-/E-ascladiol the deoxypatulin acid, and have revealed the main mechanism of patulin biotransformation/biodegradation ( $\mathrm{Li}$ et al., 2019; Wei et al., 2020). Recent studies have shown that adsorption using inactivated microbial cells is a promising method for efficient and economical removal of contamination (Qiu et al., 2018).

Inactivated microorganisms with large surface area, adsorptive selectivity, and abundant functional groups are sought after as adsorption agents. Due to the advantages of bio-sorption, numerous microorganisms such as lactic acid bacteria (LAB), Gluconobacter oxydans, Saccharomyces cerevisiae, and Alicyclobacillus spp. have been reported for the adsorption and the removal of PAT. However, filtration or even centrifugation are necessary processes after adsorption for the separation of it from the microbial cells. These operations are inefficient and impractical for large-scale application, which seriously restricts the application of inactivated microorganisms as adsorption agents (Qiu et al., 2018). The adsorption of PAT in apple juice using ten strains (BAL) was influenced by the toxin concentration and temperature. Researchers suggest that heat-inactivated (HI) LAB cells are more likely to have a greater ability to adsorb PAT from an aqueous solution. The magnetic separation technique is considered to be a fascinating method. The modification of microbial cells with magnetic nanoparticles (MNPs) can allow the promptly available bio-absorbents to be easily manipulated under the applied magnetic field (Sajid et al, 2018).

The three possible mechanisms for reducing patulin by microorganisms are absorption in the cell wall, degradation by intracellular or extracellular enzymes (Zheng et al, 2020).

For example, an inactivated Alicyclobacillus spp. can efficiently reduce the concentration of patulin in apple juice through biosorption (Yuan et al., 2014). Some yeasts have potential as biocontrol agents since they compete for nutrients and inhibit the growth of opportunistic microorganisms and plant pathogens (Tang et al, 2019). Saccharomyces cerevisiae, Gluconobacter oxydans, and Lactobacillus plantarum are effective in reducing the content of patulin and transforming it into the Z- / E-ascladiol isomer. In addition, Rhodosporidium kratochvilovae, strain LS11, and Rhodosporidium paludigenum are 
responsible for the degradation of patulin into deoxypatulin acid, which is a less toxic compound, resulting in significant removal of patulin ( $\mathrm{Li}$ et al, 2019).

Lactic acid bacteria (LAB), which are widely used as a probiotic for humans, are even more advantageous in the removal of patulin contamination, as they can degrade patulin into non-toxic compounds. The adsorption of patulin across the surface of the LAB is the primary mechanism for removing patulin. Studies have shown that the main functional groups involved in patulin adsorption are polysaccharides and/or proteins. Studies confirm the bacterial surface layer protein as the PAT binding site (Wei et al, 2020). Currently, only a few strains of LAB have been identified as having the potential use to control patulin contamination in food (Zheng et al, 2020). Lactobacillus brevis 20023 (LB-20023) removed PAT from a working solution $\left(4.0 \times 10^{3} \mu \mathrm{g} / \mathrm{L}\right)$ at $37^{\circ} \mathrm{C}$ for a period of $48 \mathrm{~h}$ (Wang et al., 2015). This organism, which has a large surface area and cell wall volume, reduced the concentration of PAT by $65.02 \%$. In another study, Rhodotorula mucilaginosa JM19 significantly degraded PAT $\left(1.0 \times 10^{5} \mu \mathrm{g} / \mathrm{L}\right)$ in deoxypatulinic acid (DPA) in a MES buffer at $35^{\circ} \mathrm{C}$ for $21 \mathrm{~h}$, with, in some cases, a degradation rate greater than $90 \%$. Interestingly, another study of Saccharomyces cerevisiae reported a $100 \%$ degradation rate for PAT $(50 \mu \mathrm{g} / \mathrm{L})$ after 2 days. In that report, PAT degradation was identified as an enzymatic hydrolysis reaction, even though the enzymes that metabolize PAT were not induced by incubation with PAT (Wei et al, 2020).

It is essential to assess the toxicity of patulin degradation products (Zheng et al, 2018). The biological method not only effectively controls the hazard caused by Penicillium expansum, but also removes toxins that already exist in food. Degradation of patulin by microorganisms or biodegradation enzymes is an efficient and promising method for the removal of patulin in food if the microorganisms used and the degradation products are completely non-toxic. However, the toxicities of DPA, ascladiol, and hydroascladiol should be subjected to an intensive study.

\section{Conclusions}

The incidence of PAT contamination remains high, despite global efforts to reduce the levels of this mycotoxin at each stage of the fruit production process. Several physicals, chemical, and biological technologies have been developed for the adsorption of patulin. However, most of these techniques are less available and due to their high cost, they are not suitable for industrial manufacturing or the introduction of new chemical hazards. Generally, ideal detoxification methods should: destroy or remove the toxin, not produce or leave any new toxic substances, retain nutritional value and product acceptability, not change significantly the product processing technology, if possible, destroy fungal spores, and to be practical to the ex tent as if it is technologically and economically viable. Nevertheless, all of the aforementioned detoxification techniques have defects that do not completely satisfy the ideal conditions. The development of physical methods to remove patulin depends on the development of new dedicated equipment. The chemical methods are economic and efficient, but only if it is ensured that there are not any unknown reactions or toxic sub-products with the use of those chemicals.

Based on the premises discussed in this article on how patulin can contaminate food, affecting the quality of products as well as the effects on health. Thus, as evidenced in this review, there is no single method that completely satisfies the requirements for the ideal detoxification of patulin in food. Currently, a combination of several methods may be the best choice for removing or degrading patulin from food. Therefore, more attention should be paid to the development of advanced detoxification methods in the future.

\section{Acknowledgements}

This work was carried out with the support of the Coordenação de Aperfeiçoamento de Pessoal de Nível Superior Brazil (CAPES) - Financing Code 001, University of Minho, Rio de Janeiro State Research Foundation (FAPERJ, E26.202749/2018) and National Council for Scientific and Technological Development (CNPq, 311936/2018-374 0) 


\section{References}

Abia, W. A., Warth, B. Ezekiel, C. N., Sarkanj, B., Turner, P. C., Marko, D., Krska, R., \& Sulyok, M. (2017). Uncommon toxic microbial metabolite patterns in traditionally home-processed maize dish (fufu) consumed in rural Cameroon. Food and Chemical Toxicology, 107, 10-19. https://doi.org/10.1016/j.fct.2017.06.011

Basso, T. (2019). Quantificação de patulina em sucos de maçã disponíveis no mercado Sul brasileiro. Dissertação, Faculdade de Ciências da Saúde, Porto, 2019 .

Bayraç, C. \& Camizci, G. (2019). Adsorptive removal of patulin from apple juice via sulfhydryl-terminatedmagnetic bead-based separation. Journal of Hazardous Materials, 366, 413-422. https://doi.org/10.1016/j.jhazmat.2018.12.001

Diao, E., Hou, H., Hu, W., Dong, H., \& Li, X. (2018). Removing and detoxifying methods of patulin: A review. Trends in Food Science \& Technology, 81, 139-145. https://doi.org/10.1016/J.TIFS.2018.09.016

Gonçalves, A., Palumbo, R., Guimarães, A., Gkrillas, A., Dall Asta, C., Dorne, J. L., Battilani, P., \& Venâncio, A. (2019). The Route of Mycotoxins in the Grape Food Chain. American Journal of Enology and Viticulture, 71(2), 89-104 . https://doi: 10.5344/ajev.2019.19039

Iqbal, S. Z., Malik, S., Asi, M. R., Selamat, J., \& Malik, N. (2018). Natural occurrence of patulin in different fruits, juices and smoothies and evaluation of dietary intake in Punjab, Pakistan. Food Control, 84, 370-374 . https://doi.org/10.1016/j.foodcont.2017.08.024

Ji, X., Li, R., Yang, H., Qi, P., Xiao, Y., \& Qian, M. (2017). Occurrence of patulin in various fruit products and dietary exposure assessment for consumers in China. Food Control, 78, 100-107. https://doi.org/10.1016/j.foodcont.2017.02.044

Li, X., Tang, H., Yang, C., Meng, X., \& Liu, B. (2019). Detoxification of mycotoxin patulin by the yeast Rhodotorula mucilaginosa. Food Control, 96, 47-52. https://doi.org/10.1016/j.foodcont.2018.08.029

Ramalingam, S. \& Bahuguna, A., \& Kim, M. (2019). The effects of mycotoxin patulin on cells and cellular componentes. Trends in Food Science and Technology, 83, 99-113. https://doi.org/10.1016/j.tifs.2018.10.010

Qiu, Y., Guo, H., Guo, C., Zheng, J., Yue, T., \& Yuan, Y. (2018). One-step preparation of nano-Fe3O4 modified inactivated yeast for the adsorption of patulin. Food Control, 86, 310-318. https://doi.org/10.1016/j.foodcont.2017.10.005

Qiu, Y., Zhang, Y., Wei, J., Gu, Y., Yue, T., \& Yuan, Y. (2020). Thiol-functionalized inactivated yeast embedded in agar aerogel for highly efficient adsorption of patulin in apple juice. Journal of Hazardous Materials, 388, 121802. https://doi.org/10.1016/j.jhazmat.2019.121802.

Rodríguez-Bencomo, J. J., Sanchis, V., Viñas, I., Martín-Belloso, O., \& Soliva-Fortuny, R. (2020). Formation of patulin-glutathione conjugates induced by pulsed light: A tentative strategy for patulin degradation in apple juices. Food Chemistry, 315, 126283. https://doi.org/10.1016/j.foodchem.2020.126283

Sajid, M., Mehmood, S., Niu, C., Yuan, Y., \& Yue, T. (2018). Effective Adsorption of Patulin from Apple Juice by Using Non-Cytotoxic Heat-Inactivated Cells and Spores of Alicyclobacillus Strains. Toxins 10(9): 344. https://doi.org/10.3390/toxins10090344.

Saleh, I. \& Goktepe, I. (2019 a) Health risk assessment of Patulin intake through apples and apple-based foods sold in Qatar. Helyon, 5(11) 02754. https://doi.org/10.1016/j.heliyon.2019.e02754

Saleh, I., \& Goktepe, I. (2019 b). The characteristics, occurrence, and toxicological effects of patulin. Food Chemical Toxicology, 129, 301-311. https://doi.org/10.1016/j.fct.2019.04.036

Tang, H., Li, X., Zhang, F., Meng, X., \& Liu, B. (2019). Biodegradation of the mycotoxin patulin in apple juice by Orotate phosphoribosyltransferase from Rhodotorula mucilaginosa. Food Control, 100, 158-164. https://doi.org/10.1016/j.foodcont.2019.01.020

Vidal, A., Ouhibi, S., Ghali, R., Hedhili, A., De Saeger, S., \& De Boerve, M. (2019). The mycotoxin patulin: An updated short review on occurrence, toxicity and analytical challenges. Food and Chemical Toxicology, 129, 249-256. https://doi.org/10.1016/j.fct.2019.04.048

Wang, L., Yue, T., Yuan, Y., Wang, Z., Ye, M., \& Cai, R. (2015). A new insight into the adsorption mechanism of patulin by the heat-inactive lactic acid bacteria cells. Food Control, 50, 104-110. http://dx.doi.org/10.1016/j.foodcont.2014.08.041

Wei, C., Yo, L., Qiao, N., Zhao, N., Zhang, H., Zhai, Q., Tian, F., \& Chen, W. (2020). Progress in the distribution, toxicity, control, and detoxification of patulin: A review. Toxicon, 184, 83-93. https://doi.org/10.1016/j.toxicon.2020.05.006

Yuan, Y., Wang, X., Hatab, S., Wang, Z., Wang, Y., Luo, Y., \& Yue, T. (2014). Patulin reduction in apple juice by inactivated Alicyclobacillus spp. Lett Appl Microbiol, 59(6):604-9. doi: 10.1111/lam.12315. Epub 2014 Aug 28. PMID: 25130934.

Xiao, Y., Liu, B., Wang, Z., Han, C., Meng, X., \& Zhang, F. (2019). Effective degradation of the mycotoxin patulin in pear juice by porcine pancreatic lipase. Food and Chemical Toxicology , 133, 110769. https://doi.org/10.1016/j.fct.2019.110769

Zhao, M., Shao, H., He, Y., Li, H., Yan, M., Jiang, Z., Wang, J., Abd El-Aty, A. M., Hacimüftüoglu, A., Yan, F., Wang, Y., \& She, Y. (2019). The determination of patulin from food samples using dual-dummy molecularly imprinted solid-phase extraction coupled with LC-MS/MS. Journal of Chromatography B, 1125, 121714. https://doi.org/10.1016/j.jchromb.2019.121714

Zhang Z, Li, M, Wu C, \& Peng B. (2019). Physical adsorption of patulin by Saccharomyces cerevisiae during fermentation. Journal Food Science and Technology, 56, 2326-2331. http://doi:10.1007/s13197-019-03681-1

Zheng, X., Li, Y., Zhang, H., Apaliya, Z. M., Zhang, X., Zhao, L., Jiang, Z., Yang, Q., \& Gu, X. (2018). Identification and toxicological analysis of products of patulin degradation by Pichia caribbica. Biological Control, 123, 127-136. https://doi.org/10.1016/j.biocontrol.2018.04.019. 
Research, Society and Development, v. 10, n. 6, e58310616162, 2021

(CC BY 4.0) | ISSN 2525-3409 | DOI: http://dx.doi.org/10.33448/rsd-v10i6.16162

Zheng, X., Wei, W., Rao, S., Gao, L., Li, H., \& Yang, Z. (2020). Degradation of patulin in fruit juice by a lactic acid bacteria strain Lactobacillus casei YZU01. Food Control, 112, 107147. https://doi.org/10.1016/j.foodcont.2020.107147

Zhu, Y., Koutchma, T., Warriner, K., \& Zhou, T. (2014). Reduction of patulin in apple juice products by UV light of different wavelengths in the UVC range. Journal of Food Protection, 77(6), 963-971. https://doi.org/10.4315/0362-028X.JPP-13-429 